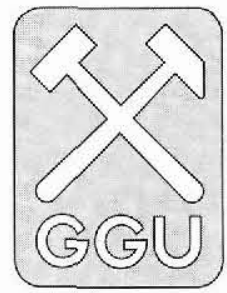

\title{
Greenland glaciers and the 'greenhouse effect', activities 1993
}

\author{
Roger J. Braithwaite, Ole B. Olesen, \\ Niels Reeh and Anker Weidick
}

Possible global climate change caused by increased 'greenhouse effect' may lead to a warmer climate that will cause increased melting of the Greenland ice sheet, and a rise in world sea level. Climate warming may be apparent first, and with greatest magnitude, at high latitudes so that increased melting of the Greenland ice sheet could give early warning of global climate change. For these reasons, GGU and foreign organisations are studying Greenland glaciers in connection with the 'greenhouse effect' (Braithwaite et al., 1992).

In 1993, GGU completed a 2-year project (1991-1993) for the European Community (EC) under its EPOCH programme with a final report (Braithwaite, 1993) and started work on a new 2-year project for the EC in close partnership with the Danish Polar Center (DPC).

The Alfred Wegener Institute for Polar and Marine Research (AWI), Germany, and the Institute of Marine and Atmospheric Research (IMAU), the Netherlands, also work in Greenland as foreign partners in these EC projects. During 1993, IMAU continued earlier Dutch work to the east of Kangerlussuaq/Søndre Strømfjord (Fig. 1). Besides cooperation with DPC in North-East Greenland, AWI also conducted an over-snow traverse from Summit towards North-East Greenland which will terminate in Thule in summer 1994 (Fig. 1).

\section{Ablation-climate studies in Kronprins Christian Land}

Most ablation-climate studies have been made in West Greenland, and models for the whole Greenland ice sheet involve extrapolations which may not be valid because ablation-climate regimes are different. For example, the best mass balance model of the whole ice sheet is by Huybrechts et at. (1991) but it still uses degree-day factors found in West Greenland (Braithwaite \& Olesen, 1989; Reeh, 1991). The variability of degree-factors is now being examined critically by energy balance modelling and by collection of new field data in North Greenland to compare with conditions in West Greenland.

A reconnaissance glacier-climate study was carried out in July 1993 in Kronprins Christian Land (Fig. 1) in logistic cooperation with GGU's geological mapping project in the area (Henriksen, this report). The 1993 field work involved daily measurements of ablation over 20 days at 10 stakes drilled near to the ice sheet margin, measurements of englacial temperature profiles to a depth of 3 metres, and parallel datalogging of air temperature, humidity and wind speed. Continuous recording of shortwave and allwave radiation was made near the ice margin by $\mathrm{T}$. Konzelmann (Swiss Federal Institute of Technology, Zurich) who also studied small-scale variations of albedo around the site of ablation measurements.



Fig. 1. Locations of glaciological studies in connection with the 'greenhouse effect' in 1993 
The measurement period was characterised by high winds and clear skies so turbulent heat flux and shortwave radiation were both relatively strong sources of ablation energy. They were, however, partly offset by high evaporative heat flux and strong conduction into the near-surface active layer of the glacier. The degree-day factor seems to be $c .20$ percent higher than found in West Greenland, and is mainly due to the high wind speeds.

Besides the detailed ablation study near the ice margin, stakes were installed at $100 \mathrm{~m}$ altitude intervals up to $1300 \mathrm{~m}$ a.s.1., which is $c .60 \mathrm{~km}$ from the ice margin. The stakes are used for studies of mass balance and ice dynamics which will be continued by AWI in 1994. Surface ice samples were also collected in a $1 \mathrm{~km}$ profile at the ice margin for stable oxygen-isotope analysis. This profile, sampled at an ice margin site which appears undisturbed by ice dynamics, is expected to provide information about climate in North Greenland during the last glacial cycle.

\section{Outlet glacier dynamics and iceberg calving, Storstrømmen}

Present estimates of sea-level contributions from glaciers and ice sheets under increased 'greenhouse effect' only account for changes of the surface mass balance. The rate of iceberg calving, which at present constitutes about half of the mass loss from the Greenland ice sheet, is assumed to remain unchanged at its present value on the decade to century time-scale. This assumption is now being critically reviewed by developing a dynamic model for Greenland outlet glaciers to predict changes in calving flux in response to changing climatic conditions.

Field work was carried out in 1993 on Storstrømmen (Fig. 1) by DPC in cooperation with AWI as a continuation of earlier work by AWI under the EPOCH project (Reeh $e t$ al., 1993). Storstrømmen is a large outlet glacier from the north-eastern part of the Greenland ice sheet, draining about 2 percent of the total mass input. By comparison, Jakobshavn Isbræ in West Greenland is the largest outlet glacier from the ice sheet and drains about 5 to 7.5 percent of the total mass input.

In the 1993 field season, previously established ablation stakes were used to measure mass balance and were resurveyed to determine ice velocities. New stakes were also drilled close to the calving front. The stakes were positioned by Global Positioning System (GPS) both at the beginning and the end of the field season, so velocities can be estimated already this year. However, all stakes will be re-positioned in 1994 to obtain more precise velocities.

An airborne-radar survey of Storstrømmen was made in July 1993 as part of the field activities of GRIP (Greenland Ice Sheet Project). A total of $560 \mathrm{~km}$ of echo-sounding profiles were obtained to determine surface elevation and ice-thickness distributions of the glacier.

Studies of aerial photographs and satellite images of Storstrømmen show that the glacier front advanced by about 12 kilometres between 1978 and 1984, whereby about $50 \mathrm{~km}^{3}$ of ice were transferred from the upper to lower reaches of the glacier. During this 'surge-like' event, ice velocities near the front must have reached at least 2000 metres per year. The recent field observations show that the phase of rapid motion has now stopped and the frontal region is nearly stagnant, so the front of the glacier which advanced during the surge can be expected to decay in the near future by melting and calving. This is the first detailed documentation of a surge of a large outlet glacier from the Greenland ice sheet. The fact that this kind of unsteady motion can occur must be considered when assessing the loss of mass by iceberg calving from the Greenland ice sheet, and is also important for understanding calving flux changes in response to a changing climate.

An international workshop on 'Calving Rate of West Greenland Glaciers in Response to Climate Change' was held in Copenhagen, 13-15 September 1993, by the Danish Polar Center with funding from the Canadian Federal Panel on Energy Research and Development. No doubt the present project will benefit from the state-of-the-art presentations at this workshop.

\section{Neoglacial changes of the Greenland ice sheet}

The time since the Holocene climatic optimum is important for understanding glacier-climate changes. Its proximity to the present implies a variety of information, spanning from archaeological and historical records to modern instrumental data, which can supplement geologically determined events. The time coverage (4000-5000 years) is long enough to evaluate response lags of the effect of climate on the ice sheet including glacio-isostatic effects (Weidick, 1993).

The present work is a follow-up to studies around Jakobshavn Isbræ (Fig. 1) in West Greenland (Weidick et al., 1990; Weidick, 1992) which were made in collaboration with mass balance studies and ice margin datings by stable isotopes (Reeh et al., 1991). The work involves ${ }^{14} \mathrm{C}$ dating of organic materials (preferably marine shells) to determine the extent and timing of deglaciation during the Holocene and the subsequent neoglacial advance to present extent. The study of the Holocene deglaciation was also extended to the western slope of the ice sheet (Godthåbsfjord), the southern slope (Qassimiut) and the north-eastern slope (Storstrømmen).

The investigation around Storstrømmen in Germania Land, North-East Greenland, is coordinated with the AWI/ DPC studies of present mass balance, dynamics and isotope 
age determination. The results here show that Germania Land was an island isolated by the sea from the ice sheet at least in the period 5000-2000 years BP. Such a reduced state of the ice sheet also occurred at two older events of the Quaternary epoch which must be correlated with interstadials and interglacials of the isotopic climate record from the deep core at the centre of the ice sheet.

\section{Reconnaissance of Hans Tausen Iskappe}

DPC will continue studies on Storstrømmen in 1994 while the focus of GGU/DPC work in North Greenland will shift from Kronprins Christian Land to Hans Tausen Iskappe (Fig. 1). In this connection two reconnaissance flights were made in July 1993 (by Twin Otter) to Hans Tausen Iskappe to choose working areas for studies in 1994-1996. One flight involved measurements of ice thickness by airborne radar to choose the site for a planned deep drilling project while the ice margin was inspected on the other flight.

Acknowledgements. Work in 1993 by GGU and DPC is supported by the European Community through contract EV5V-CT910051 which is coordinated by the Climatic Research Unit, University of East Anglia, U.K.

\section{References}

Braithwaite, R. J. 1993: Mass balance studies of the Greenland ice sheet. Final report to the European Community under Contract no. EPOC-CT90-0015. 18 pp. Copenhagen: Geol. Surv. Greenland.

Braithwaite, R. J. \& Olesen, O. B. 1989: Calculation of glacier ablation from air temperature, West Greenland. In Oerlemans,
J. (ed.) Glacier fluctuations and climatic change, 219-233. Dordrecht: Kluwer Academic Publishers.

Braithwaite, R. J., Reeh, N. \& Weidick, A. 1992: Greenland glaciers and the 'greenhouse effect', status 1991. Rapp. Gronlands geol. Unders. 155, 9-13.

Huybrechts, P., Letréguilly, A. \& Reeh, N. 1991: The Greenland ice sheet and greenhouse warming. Palaeogeogr., Palaeoclimatol., Palaeoecol. (Global planet. Change Sect.) 89, 399-412.

Reeh, N. 1991: Parameterization of melt rate and surface temperature on the Greenland ice sheet. Polarforschung 59/3, 113128.

Reeh, N., Oerter, H., Letréguilly, A., Miller, H. \& Hubberton, H. W. 1991: A new detailed ice-age oxygen-18 record from the icesheet margin in central West Greenland. Palaeogeogr., Palaeoclimatol., Palaeoecol. (Global planet. Change Sect.) 90, 373 383.

Reeh, N., Oerter, H. \& Bøggild. C. E. 1993: Mass balance and ice dynamics of the North-East Greenland ice-sheet margin. Final report to the European Community under Contract no. EPOCCT90-0015. Alfred Wegener Institut für Polar- und Meeresforschung, Bremerhaven, 21 pp.

Weidick, A. 1992: Jakobshavn Isbræ area during the climatic optimum. Rapp. Grønlands geol. Unders. 155, 67-72.

Weidick, A. 1993: Neoglacial change of ice cover and the related response of the Earth's crust in West Greenland. Rapp. Grønlands geol. Unders. 155, 67-72.

Weidick, A., Oerter, H., Reeh, N., Thomsen, H. H. \& Thorning, L. 1990: The recession of the Inland Ice margin during the Holocene climatic optimum in the Jakobshavn Isfjord area of West Greenland. Palaeogeogr, Palaeoclimatol, Palaeoecol. (Global planet. Change Sect.) 82, 389-399.

R. J. B., O. B. O.\&A. W., Geological Survey of Greenland, Copenhagen

N. R., Danish Polar Center, Strandgade 100 H, DK-1401 Copenhagen $K$, Denmark 